\title{
Minireview
}

\section{Is negative turgor fallacious?}

\author{
Sophia Rhizopoulou
}

\begin{abstract}
Rhizopoulou, S. 1997. Is negative turgor fallacious? - Physiol. Plant. 99: 505-510.
In early studies, negative turgor pressure was obtained by indirect methods and was mainly related to inaccurate measurements of osmotic and/or water potential. The uncertainties in the meastrements made any discussion of the underlying reasons and phenomena premature and risky, perhaps even useless. Yet, the idea of relating negative turgor to the strength of small-sized cells with thick walls, to resist collapse when subjected to water deficit, seemed attractive. Negative turgor pressures are difficult to detect in higher plants, but they are theoretically possible. Regarding their origin, a hypothesis is discussed here, that the negative urgor detected in leaves might indicate a reversal of the water flow that has occurred in roots, under conditions of severe and prolonged drought.
\end{abstract}

Key words - Drotght, reverse flow, turgor.

S. Rhizopoulou (e-mail srhizop@atlas.uoa.gr), Inst. of General Botany, Dept of Biology, Univ: of Athens, Athens 15784, Greece.

\section{Introduction}

Negative turgor $\left(\Psi_{p}\right)$ is a tension in the cell lumen that develops when the intracellular osmotic pressure difference, i.e. between the cells and the apoplastic space, is larger than the turgor pressure. Such a case can be envisaged for a transpiring plant when the cell turgor drops considerably, because of water loss and rate-limiting water supply from the roots (Zimmermann et al. 1993). Consequences of negative $\Psi_{\mathrm{p}}$ are the risk of cavitation and/or of collapse of the cell walls (Oertli 1993).

Abbreviations - $\Psi$, water potential; $\Psi_{\mathrm{p}}$, turgor potential; $\Psi_{\mathrm{s}}$, osmotic potential.

\section{Fallacy}

In the mid-1970s, Tyree (1976) argued that reports on negative turgor were fallacious due to the techniques used. In these studies, the pressure chamber and cryoscopic and psychrometric techniques had been used (Grieve 1961, Lösch and Franz 1974, Turner 1974, Kappen et al. 1975, Campbell and Harris 1977, Margaris 1977, Karlic and Richter 1983). Tyree (1976) argued that the leaf osmotic potential $\left(\Psi_{s}\right)$ increased to values less negative than those of the corresponding water potential $(\Psi)$, because symplasmic solutes diffused into the relatively pure apoplastic water, leading artifactually, to apparent negative turgor. Also, negative turgor can arise from enrors in measured $\Psi_{\text {lear, }}$ because of rapid water loss in the pressure chamber technique (Tumer and Long 1980).

After a critical evaluation of the results obtained with the pressure-volume (PV) curve method (Kyriakopoulos and Richter 1977, 1981, Roberts et al. 1980), the existence of negative turgor appeared doubtful. This is the preferred technique for accurate turgor estimates, because dilution errors are avoided and $\Psi$ and $\Psi_{\mathrm{s}}$ are measured on the same tissue (Turner 1981). However, errors in $\Psi_{\mathrm{s}}$ and $\Psi_{\mathrm{p}}$ estimates obtained by this technique for arid-land shrubs can arise from ontogenetic and rehydration-induced changes in leaf material (Evans et al. 1992 and references therein, Lösch 1995).

The analysis of the water potential isotherms assumes that negative turgor does not develop in living cells (Tyree and Jarvis 1982). However, Tyree (1976) mentioned that his method of plotting the isotherm of $-1 / \Psi$ vs relative water content could overlook small negative turgor 
pressures of a few bars. Also, Tyree and Richter (1982) concluded - by computing the theoretical isotherm of a hypothetical shoot having eight different cell types, all capable of developing negative turgor - that negative turgor could contribute up to $10 \%$ of the measured $\Psi$ without being detected. The properties of plant tissue that may determine the magnitude of error in water potential isotherm analysis, are the apoplastic osmotic potential, the relative volumes of apoplast and symplast, the morphology of the xylem, the nature of cavitation and air entry events (Hardegree 1989); such properties are highly variable among species. Recently, it was argued by Parker and Colombo (1995) that none of the PV procedures (i.e. the composite, repeat-pressurization and sap expression method) should be unconditionally accepted as providing accurate estimates of water relation attributes.

Tyree (1976) noted "it is perhaps disappointing that negative pressures do not exist in arid-zone plants because if negative pressure did develop, it could reduce the net water loss of plants during drought". Consider a cell that has reached zero turgor and $\Psi$ drops further. A cell containing a constant number of solutes, will adjust its $\Psi$ to the new conditions by changing volume and/or pressure (see also Spence and Wu 1995). If the walls are elastic this may cause a shrinkage and maintenance of turgidity (Fan et al. 1994). A cell with rigid walls will resist such a shrinkage and turgor will be reduced at a constant volume (Cheung et al. 1975, Rhizopoulou and Davies 1991). In this case negative turgor might be possible, as the environment dries and the tissue water potentials fall.

Zimmermann and Steudle (1978) have drawn attention to the problem of negative turgor and pointed out that from a physical standpoint, a solution can indeed be under a negative pressure but is not thermodynamically stable, since its free energy is diminished if it is allowed to break up by the process of cavitation (formation of water vapor and gas bubbles in a liquid). However, such a metastable state can persist if the pressures are not too negative (Oertli 1993, Zimmermann et al. 1993).

Since Tyree's publication (1976), negative turgor pressure has no longer been considered as an acceptable issue of plant water relations (Oertli 1989) and reports with such views have been largely criticized as inaccurate and misguided. The evidence against the existence of negative turgor, though, was based on the available methodology, which focused on leaf water relations, and which by no means was infallible; yet, theory did not rule out moderate negative turgor (Richter 1976).

\section{Uncertainty}

In the 1980 s, negative turgor was studied on a more theoretical basis (Markhart et al. 1981, Manjavidze 1986, Oertli 1986a, 1989, Oertli et al. 1990). Steudle and Heydt (1988) developed an artificial osmotic cell for studying phenomena of negative pressure in plants. The pressure-probe technique was used to record direct mea- surements of negative turgor, which was artificially generated on individual cells in glass capillaries (Balling et al. 1988). The miniaturized cellular pressure probe is the only method available for direct measurement of turgor in cells of higher plants (Hüsken et al. 1978); a new probe monitoring cell turgor followed the same principle (Zhu 1996). This method requires physical puncture of the wall and hence the destruction of the cell (Kutschera 1995). Meidner and Sheriff (1976) noted that the puncturing of the cell releases the prevailing pressure, and this measurement is lost. Also, introduction of a sensor into the liquid carries with it a high risk of inducing cavitation (Oertli 1989, Benkert et al. 1991). Oertli et al. (1990) claimed that small negative turgor pressures could not be detected with the current methodology.

It is noticeable, though, that values of negative turgor in the order of $\mathrm{kPa}$ have been calculated for mesophytic tissues (Tumer 1974, Oertli 1993); those for woody sclerophylious plants, during the drought period, appear to be greater, of the order of bars (Grieve 1961, Noy-Meir and Ginzburg 1969; S. Rhizopoulou 1986. Thesis, University of Athens, Athens, Greece).

Larcher (1975) wrote that negative turgor in scleromorphic leaves can enhance considerably the effective suction exerted by the protoplasts. He assumed "the ecological advantage of this for the sclerophylls is evident; the effective suction can reach high values without an excessive rise in osmotic pressure". Full saturation caused a marked increase in $\Psi_{\text {leaf }}$ of evergreen sclerophylls, but the effect on $\Psi_{\text {silear }}$, was much smaller and in most cases seems to be random, with the differences between young and overwintered leaves becoming insignificant as early as July (Rhizopoulou and Mitrakos 1990, Kyriakopoulos and Richter 1991). These species exhibit a short growth period that is completed before the onset of the dry summer (Rhizopoulou et al. 1991), a deep tap root system (Kummerow and Mangan 1981, Rhizopoulou and Davies 1991 ) and small cells with thick walls (Oertli et al. 1990 , Christodoulakis 1992). A larger cell is expected to collapse at a lower intracellular pressure difference than a smaller cell of the same composition and thickness, because the force causing the collapse is the product of a pressure difference across the wall and the surface area perpendicular to the direction of the force (Oertli 1986b). Steudle et al. (1977) suggested that smaller cells require less turgor to achieve their growth potential than do larger cells, and that much more turgor pressure is necessary to stretch the cell wall to initiate extension growth in the larger cells. During a severe water shortage the internal pressure of cells is smaller than outside pressure and a compressive stress is imposed on the cell walls. Thick walls inhibit the collapse of cells under the influence of large tensions developed in the xylem. Markhart et al. (1981) reported that errors between 10 and $40 \%$ could be the result in $\Psi_{\mathrm{s}}$ measurements of plants with exceptionally thick cell walls, such as desert sclerophylls. Thus, cell size and wall thickness were considered as influencing $\Psi_{p}$ estimates (Cutler et al. 1977). 


\section{Reverse flow I}

How is water deficiency imposed (by drought) upon plants, under natural conditions? Schulte (1992) noted that the response of leaves to water stress is not determined only by stimuli that are sensed in the leaf, but also by sources in the roots. Our understanding of the whole plant response to water stress has been considerably enhanced (Turner 1986, Davies and Zhang 1991, Lösch 1993, McCully 1995, Slovik et al. 1995). However, it is not clear how leaf turgor can be affected by the release into the dry soil of some root exudates; for example, Hartung et al. (1990) concluded that some of the ABA found in the soil (ca $50 \mu M$ ), around the rhizosphere of Anastatica hierochuntica grown in the Negev desert, was extracted by the roots. The task of deducing what happens in the whole plant from what happens in the leaf is not an easy one, because (1) as soon as $\Psi$ at one location begins to change, an effective water flow is initiated to offset the change, from a region of less negative $\Psi$ to a region of more negative $\Psi$; (2) the degree to which $\Psi_{\text {leaf }}$ and $\Psi_{\text {root }}$ change in concert will depend on the hydraulic resistance between the root and leaf and the elasticity of the leaf and root cells (Turner 1986); and (3) very substantial gradients in $\Psi$ exist within leaf blades (Yang and Tyree 1994).

In a period of intense water shortage, a bi-directional flow of water into and out of the roots has been shown to occur (Richards and Caldwell 1987, Mahall and Callaway 1991, Changgui et al. 1993, Emerman and Dawson 1996). Roots pull up water from deep, wet soil layers and flush it into the dry ground near the surface, during the night. Water released at night moistens the dry, upper soil layers from where it is reabsorbed the following day by the shallow roots, when transpiration demand exceeds water uptake by deeper roots alone, as well as by "thirsty" shrubs living nearby. Passioura (1988) noticed that another benefit of this process to the plant may be through allowing the roots that are growing in the dry but probably nutritionally rich soil to take up some nutrients that would otherwise be inaccessible.

If soil water is available only from deep soil layers, where only a few, brownish, tap roots with a small number of white apices (McKenzie and Peterson 1995) are able to penetrate (personal observation), it is doubtful that this supply during the night is sufficient for the transpiration demands during the next day. Larcher (1975) mentioned that during dry periods, water content is not entirely restored overnight, so that a deficit accumulates from day to day.

\section{The state of the art}

Recently, sophisticated equipment and new tools have enabled plant physiologists to study previously inaccessible phenomena and to reconsider even long-established views. For example, Benkert et al. (1995) argued that the presence of mucilagious substances in the ves- sels clearly renders the use of the pressure chamber obsolete, because the measured balancing pressure may merely reflect the pressure required to squeeze water out of the gel structure and it may be poorly correlated with the in situ xylem pressure (Zimmermann et al. 1994). In the presence of mucosubstances in the xylem, numerous tiny gas bubbles can persist, establishing a liquid/air interface and an interfacial flow (the so-called Marangoni streaming). Marangoni flow may be of relevance when considering whether there exist regions in plant tissues (apart from the water-conducting vessels) in which negative pressures can be developed (Zimmermann et al. 1993, Benkert et al. 1995). Negative pressure down to -0.195 MPa was measured in secretory cells of Sparmannia africana (Zimmermann et al. 1993). Accumulation of high molecular mass secretory products may create negative pressure some distance away from the region of secre. tion (e.g. in the apoplastic spaces), if the water supply from the xylem located more deeply in the tissue is not sufficient.

Conflicting results on solute concentration in the apoplast solutions have been published (Cosgrove and Cleland 1983, Cosgrove 1987, Nonami and Boyer 1987, Boyer 1993). It seems likely that the vastly different values of apoplastic solute concentrations given in the literature depend on the object and the method of determination (Meshcheryakov et al. 1992). Canny (1995) argued that the reliability of sampling of apoplastic spaces is questionable, because the term apoplast has lost its precise meaning and begins to mean different spaces (with quite different properties) to different readers. Discrepancies between field and laboratory measurements have also been repeatedly mentioned. For example, Schurr and Schulze (1995) measured diumal changes in ABA concentration in the xylem sap which contrast to those published by Tardieu et al. (1992), mainly because of the different methods used to extract the xylem sap; i.e. pressurized cut leaves reflect the apoplastic concentration in the leaf, the diurnal variation of which may differ from that of the xylem sap, which is absorbed by the roots.

\section{Reverse now II}

Meshcheryakov et al. (1992) found reversibility of the "original" turgor and turgor gradient by withholding water from a tissue for some time. Matyssek et al. (1991a) found that growth-induced water potential was transmitted to the walls as a tension that pulled out water from the vascular system, through the frictional resistance of the intervening cells. Boyer (1993) pointed out that in case of rapidly imposed water deficiency, $\Psi$ in the apoplast became important, because gradients in $\Psi$ that were normally present between the xylem and surrounding tissues underwent a local change in shape. The gradient in $\Psi$ next to the xylem reversed direction, when $\Psi_{\text {xylem }}$ fell and water movement out of the xylem was blocked. Tyree et al. (1995) described a novel method, the high-pressure flow meter, of measuring root hydrau- 
lic conductance in the laboratory and field, that may provide a means to study why some roots in contrast to others are leaky to backwards flow of water, from roots to dry soil.

In another study, a reverse flow of water from roots of woody species to the soil has been found, during the growing period (Dawson 1993 and references therein). Dawson (1993) also reported that it takes time ( $>5 \mathrm{~h}$ ) for soil water to appear in the xylem of species with long transport pathways. On the other hand, the xylem tension which had developed during sunny days in the upper parts in the liana of Tetrastigma voinierianum was not immediately (i.e. within seconds) transmitted to the xylem of the leaves at ground level (Benkert et al. 1995). In leaves from plants grown in arid regions, a reverse water flow on the leaf-atmosphere level has been investigated (Voznesenskii 1988, Fahn and Cutler 1992 and references therein). Specialized cells (e.g. trichomes, hydathodes), epidermis, stomata and anticlinal walls of the epidermal cells absorb water from the surrounding air. This may result in a considerable increase of $\Psi_{\text {leaf }}$ (Grammatikopoulos and Manetas 1994). Also, water may be funneled by the leaves to the soil at the base of the plant (Fahn and Cutler 1992).

What does a reverse flow (from the root to the soil) mean for the leaf water relations? (In view of a rapidly imposed stress period, a simple process is presented.) In a transpiring plant, with open stomata early in the morning during the dry period, the water loss will begin in the leaves of the most distal branches (Zimmermann 1993). This will first be matched by water uptake from the hydrauticaliy connected adjacent xylem parenchyma and tracheidary cells, or from slime ducts and the apoplast (Benkert et al. 1995). At that time if $\Psi_{\text {soil }}$ is lower than $\Psi_{\text {ror }}$ (whenever there is an excess flow of water), a water potential gradient along the root system opposed to the classic water potential gradient (from less negative $\Psi_{\text {soil }}$ to more negative $\Psi_{\text {roon }}$ ) will be generated. Soon, stomata will close.

Tyree et al. (1995) reported that, because of differences in what causes axial vs radial flow of water in roots, a change in the driving force can arise; axial water flow is caused solely by hydrostatic pressure differences, but for radial flow in xylem conduit there is some osmotic barrier. In contrast, during back-flow, solutes and water travel together without separation down to the axis of roots, but water passes radially out of the roots with less selection than solutes (Tyree et al. 1995). Steudle and Henzler (1995) suggested that water transport across membranes can be regulated by the opening and the closing of water channels; in treated cells with hypertonic solutions, changes in reflection coefficients $\left(\sigma_{3}\right)$ of permeating solutes upon channel closure were remarkable and in some cases negative values of $\sigma_{5}$ were obtained. This means that anomalous osmosis occurred and cells were swelling. In this case, the water flow across a pore would drag solutes against the concentration gradient and vice versa.
If the reversed gradient (from less negative $\Psi_{\text {mot }}$ to more negative $\Psi_{\text {soij }}$ ) is steeper than the classic gradient, water will move from the shoots to the roots. A reverse flow, from shoots to roots, has been reported by Matyssek et al. (1991b). They found that the basal tissues of stems, consisting mostly of cortical-and pith-parenchyma, and the large vacuoles could represented a significant volume of water to be redistributed to other cells. Roots contained a smaller water volume. If external water was present, the basal stem increased in water content and grew slowly in diameter. When external water supply was withdrawn, water moved from the shoot to the root and the basal tissues shrank. Such changes in water potential gradient might cause a reversal of water flux within the leaf. The magnitude of the tension depends on the water exchange between the xylem and the tissue compartment.

The water potentials in a tissue form a potential field around the vascular system, with the highest potentials in the xylem and lowest potentials in the epidermal cells at the outer surface of the tissue (Boyer 1987). On the leaf-tissue level, as far as water potentials in the symplast are not equal to those in the cell walls and the water potential gradient over short distances between cell wall and cells is negligible, water will move from the apoplast to the symplast. In this case negative turgor would be possible. Such a decrease in $\Psi_{\text {leaf }}$ is a rapid change and could hardly be accompanied by a decrease in $\Psi_{s}$ except if the volume changes - and would have required flow of solutes into the cells. Active changes in $\Psi_{\mathrm{s}}$ are induced under stress, but this adaptation to soil drying is limited, by the necessity to keep up a certain hydration state of the protoplast (Richter 1976).

Direct measurement of negative turgor pressure in leaf-cells (of higher plants) seems possible. Direct negative $\Psi_{p}$ measured by reliable non-destructive techniques, in the leaf of drought tolerant species under natural conditions - where negative values have been previously reported - are not available. New techniques are mainly designed to be used for laboratory work, but it seems desirable to try to measure the water status of plant tissues under natural conditions (see Flach et al. 1995). It has been emphasized that we must not become infatuated with any particular set of techniques, but should use all tools as appropriate to answer fundamental questions on all levels of plant organization and interactions with the environment (Botanical Society of America 1995). By generally assuming that negative turgor is fallacious, we probably underestimate the plants' ability to respond to stress conditions. Further investigation is worthy and/or the aetiology for the non-existence of negative turgor should be reevaluated.

Acknowledgments - I am grateful to Dr John Halley, Prof. Russell Jones and Prof. Dimitri Katakis for reading and commenting on the manuscript. I wish to thank the staff of the Library of the Faculty of Science at Kuwait University, for generously providing numerous publications necessary for the manuscript. 


\section{References}

Balling, A., Zimmermann, U. \& Büichner, K.-H. 1988. Direct measurement of negative pressure in artificial biological systems. - Naturwissenschaften 75: 409-411.

Benkert, R., Balling, A. \& Zimmermann, U. 1991. Direct measurements of the pressure and flow in the xylem vessels of Nicotiana tabacum and their dependence on flow resistance and transpiration rate. - Bot. Acta 104: 423-432.

- , Zhu, J. J., Zimmermann, G., Türk, R., Bentrup, F.W. \& Zimmermann, U. 1995. Long-term xylem pressure measurements in the liana Tetrastigma voinierianum by means of the xylem pressure probe. - Planta 196: 804-813.

Botanical Society of America. 1995. Section report from the American Society of Plant Physiologists \& Physiological Section of the Botanical Society of America. - In Botany for the Next Millennium (E. Lawson and K. J. Niklas, eds), pp. 43-45. Am. J. Bot., Columbus, OH.

Boyer, J. S. 1987. Hydraulics, wall extensibility and wall proteins. - In Physiology of Cell Expansion during Plant Growth (D. J. Cosgrove and D. P. Knierel, eds), pp. 109121. American Society of Plant Physiologists, Rockville, MD. ISBN 0-943088-11-9.

- 1993. Temperature and growth-induced water potential. Plant Cell Environ. 16: 1099-1106.

Campbell, G. S. \& Harris, G. A. 1977. Water relations and water use patterns for Artemisia tridentata Nutt. in wet and dry years. - Ecology 58: 652-659.

Canny, M. J. 1995. Apoplastic water and solute movement: New rules for an old space. - Annu. Rev. Plant Physiol. Plant Mol. Biol. 46: 215-236

Changgui, W., Sosebee, R. E. \& McMichael, B. L. 1993. Does hydraulic lift exist in shallow-rooted species? A quantitative examination with a half-shrub Gutierrezia sarothrae. - Plant Soil 153: 11-17

Cheung, Y. N. S., Tyree, M. T. \& Dainty, J. 1975. Water relations parameters on single leaves obtained in a pressure bomb and some ecological interpretations. - Can. J. Bot. 53: 1342-1346.

Christodoulakis, N. S. 1992. Structural diversity and adaptations in some Mediterranean evergreen sclerophyllous species. Environ. Exp. Bot. 32: 295-305.

Cosgrove, D. J. 1987. Wall relaxation and the driving forces for cell expansive growth. - Plant Physiol. 84: 541-564.

- \& Cleland, R. E. 1983. Solutes in the free space of growing stem tissues. - Plant Physiol. 72: 326-331.

Cutler, J. H., Rains, D. W. \& Loomis, R. S. 1977. The importance of cell size in the water relations of plants. - Physiol. Plant. 40: 255-260.

Davies, W. J. \& Zhang, J. 1991. Root signals and the regulation of growth and development of plants in drying soil. - Annu. Rev. Plant Physiol. Plant Mol. Biol. 42: 55-76.

Dawson, T. E. 1993. Hydraulic lift and water use by plants: Implications for water balance, performance and plant-plant interactions. - Oecologia 95: 565-574.

Emerman, S. H. \& Dawson, T. E. 1996. Hydraulic lift and its significance on the water content of the thizosphere: An example from sugar maple, Acer saccharum. - Oecologia 108 273-278.

Evans, R. D., Black, R. A., Loescher, W. H. \& Fellows, R. J. 1992. Osmotic relations of the drought-tolerant shrub Artemisia tridentata in response to water stress. - Plant Cell Environ. 15: 49-59.

Fahn, A. \& Cutler, D. F. 1992. Xerophytes. - In Encyclopedia of Plant Anatomy (H. J. Brawn, S. Carlquist, P. Ozenda and I. Roth, eds), Vol. XIII, pp. 73-76. Gebrïder-Borntraeger, Berlin. ISBN 3-443-14019-X.

Fan, S., Blake, T. J. \& Blumwakd, E. 1994. The relative contribution of elastic and osmotic adjustment to turgor maintenance of woody species. - Physiol. Plant. 90: 408-413.

Flach, B. M.-T. Eller, B. M. \& Egli, A. 1995. Transpiration and water uptake of Senecio medley-woodii and Aloe jucunda under changing environmental conditions: Measurements with the potometric water-budget-meter. - J. Exp. Bot. 46: 1615-1624.

Grammatikopoulos, G. \& Manetas, Y. 1994. Direct absorption of water by hairy leaves of Phlomis fruticosa and its contribution to drought avoidance. - Can. J. Bot. 72: 1805-1811.

Grieve, B. 1961. Negative turgor pressures in sclerophyll plants. - Aust. J. Sci. 23: 375-377.

Hardegree, P. S. 1989. Discrepancies between water potential isotherm measurements on Pinus pondersosa seedling shoots: Xylem hysteresis and apoplasmic osmotic potentials. - Plant Cell Environ. 12: 57-62.

Hartung, W., Heilmeier, H., Wartinger, A., Kettemann, I. \& Schulze, E.-D. 1990. Fonic content and abscisic acid relations of Anastatica ierochuntica L. under arid conditions. Ist. J. Bot. 39: 373-382.

Hüsken, D., Steudle, E. \& Zimmermann, U. 1978. Pressure probe for measuring water relations of cells in higher plants. - Plant Physiol. 61: 158-163.

Karlic, H. \& Richter, H. 1983. Developmental effects on leaf water relations of two evergreen shrubs (Prunus laurocerasus $\mathrm{L}$. and Ilex aquifolium L.). - Flora 173: 143-150.

Kappen, L., Oertli, J. J., Lange, O. L., Schulze, E.-D., Enevari, M. \& Bushbom, U. 1975. Seasonal and diurnal course of water relations of the arid-active plant Hammada scoparia in the Negev Desert. - Oecologia 21: 175-192.

Kummerow, J. \& Mangan, R. 1981. Root system in Quercus dumosa Nutt. dominated chaparral in southern California. Oecol. Plant. 16: 177-188.

Kutschera, U. 1995. Tissue pressure and cell turgor in axial plant organs: Implications for the organismal theory of multicellularity. - J. Plant Physiol. 146: 126-132.

Kyriakopotzlos, E. \& Richter, H. 1977. A comparison of methods for determination of water status in Quercus ilex L. - Z. Pflanzenphysiol. 82: 14-27.

- \& Richter, H. 1981. Pressure-volume curves and drought injury. - Physiol. Plant. 52: 124-128.

- \& Richer, H. 1991. Dessication tolerance and osmotic parameters in detached leaves of Quercus ilex $\mathrm{L}$. Acta Oecol 12: $357-367$.

Lösch, R. 1993. Plant water relations. - Progr. Bot. 54: 102133.

- 1995. Plant water relations. - Progr. Bot. 56: 56-96.

- \& Franz, N. 1974. Tagesverlauf von Wasserpotential und Wasserbilanz bei Pflanzen verschiedener Standorte des fränkischen Wellenkaltes. - Flora 163: 466-479.

Larcher, W. 1975. Physiological Plant Ecology. - Springer-Verlag, Berlin. pp. 137-165. ISBN 3-540-07336-1.

Mahall, B. E. \& Callaway, R. M. 1991. Root communication among desert shrubs. - Proc. Natl. Acad. Sci. USA 88: 874876.

Manjavidze, Z. D. 1986. On negative turgor pressure in plants. Izv. Akad. Naur. SSR Ser. Biol. 5: 790-793 (In Russian).

Margaris, N. S. 1977. Water relations in plants dominating phryganic ecosystems. - Biol. Plant. 19: 442-447.

Markhart, A. H. III, Sionit, N. \& Siedow, J. N. 1981. Cell wall water dilution: An explanation of apparent negative turgor potentials. - Can. J. Bot. 59: 1722-1725.

Matyssek, R., Maruyama, S. \& Boyer, J. S. 1991a. Growth-induced water potentials may mobilize internal water for growth. - Plant Cell Environ. 14: 917-923.

- , Tang, A.-C. \& Boyer, J. S. 1991b. Plants can grow on internal water. - Plant Cell Environ. 14: 925-930.

McCully, M. 1995. How do real roots work? - Plant Physiol. 109: 1-6.

McKenzie, E. B. \& Peterson, C. A. 1995. Root browning in Pinus banksiana Lamb. and Eucalyptus pilularis Sm. I. Anatomy and permeability of the white and tannin zones. - Bot. Acta 108: 127-137.

Meidner, H. \& Sheriff, D. W. 1976. Water and Plants. - Blackie Glasgow and London. pp. 116-124. ISBN 0-216-90081-6.

Meshcheryakov, A., Steadle, E. \& Komor, E. 1992. Gradients of turgor, osmotic pressure, and water potential in the cortex of the hypocotyl of growing Ricinus seedlings. Effects of sup- 
ply of water from the xylem and of solutes from the phloem. - Plant Physiol. 98: 840-852.

Nonami, H. \& Boyer, J. S. 1987. Origin of growth-induced water potential: Solute concentration is low in the apoplast of enharging tissues. - Plant Physiol. 83: 596-601.

Noy-Meir, 1. \& Ginzburg, B. Z. 1969. An analysis of the water potential isotherm in plant tissue. II. Comparative studies of leaves of different types. - Aust. J. Biol. Sci. 22: 35-52.

Oerti, J. J. 1986a. Negative turgor pressures in plant cells. $-Z$. Pflanzenernaehr. Bodenkd. 149: 60-67.

- $1986 \mathrm{~b}$. The effect of cell size on cell collapse under negative turgor pressure. - J. Plant Physiol. 124: 365-370.

- 1989. The plant cell's resistance to consequences of negative turgor pressure. - In Structural and Functional Responses to Environmental Stresses: Water Shortage (K. H. Kreeb, H. Richter and T. M. Hinckley, eds), pp. 73-88. SPB Academic Publishing bv, The Hague. ISBN 90-5103-027-4.

- 1993. Effect of cavitation on the status of water in plants. In Water Transport in Plants under Climatic Stress (M. Borghatti, J. Grace and A. Raschi, eds), pp. 27-40. Cambridge University Press, Cambridge. ISBN 0-521-44219-2.

- , Lips, S. H. \& Agami, M. 1990. The strength of sclerophyllous cells to resist collapse due to negative turgor pressure. Acta Oecol. 11: 281-289.

Parker, W. C. \& Colombo, S. J. 1995. A critical re-examination of pressure-volume analysis of conifer shoots: Comparison of three procedures for generating PV curves on shoots of Pinus resinosa Ait. seedlings. - J. Exp. Bot. 46: 1701-1709.

Passioura, J. B. 1988. Water transport in and to roots. - Annu. Rev. Plant Physiol. Plant Mol. Biol. 39: 245-265.

Rhizopoulou, S. \& Davies, W. J. 1991. Influence of soil drying on root distribution, water relations and leaf growth of Ceratonia siliqua L. - Oecologia 88: $41-47$.

- \& Mitrakos, K. 1990 . Water relations of evergreen sclerophylls. I. Seasonal changes in the water relations of eleven species from the same environment. - Ann. Bot. 65: 171178.

- , Meletiou-Christou, M. S. \& Diamantoglou, S. 1991. Water relations for sun and shade leaves of four Mediterranean evergreen sclerophylls. - J. Exp. Bot. 42: 627-635.

Richards, J. H. \& Caldwell, M. M. 1987. Hydraulic lift: Substantial noctumal water transport between soil layers by $A r$ temisia tridentata roots. - Oecologia 73; 486-489.

Richter, H. 1976. The water status in the plant. Experimental evidence. - In Water and Plant Life (O. L. Lange, L. Kappen and E.-D. Schulze, eds), pp. 42-58. Springer-Verlag, Berlin. ISBN 3-540-07838-X.

Roberts, S. W., Strain, B. R. \& Knoerr, K. R. 1980. Seasonal pattems of leaf water relations in four co-occurring forest tree species: Parameters from pressure-volume curves. Oecologia 46:330-337.

Schulte, P. J. 1992. The units of currency for plant water status. - Plant Cell Environ. 15: 7-10.

Schurr, U. \& Schulze, E.-D. 1995. The concentration of xylem sap constituents in root exudate, and in sap from intact, transpiring castor bean plants (Ricinus communis L.). - Plant Cell Environ. 18: 409-419.

Slovik, S., Daeter, W. \& Hartung, W. 1995. Compartmental redistribution and long-distance transport of abscisic acid (ABA) in plants as influenced by environmental changes in the thizosphere - a biomathematical model. - J. Exp. Bot. 46: 881-894.

Spence, R. D. \& Wu, H. 1. 1995. Plant cell wall elasticity. III. A polymer elastic interpretation of inverse pressure-volume curves. - J. Theor. Biol. 177: 59-65.
Steadle, E. \& Henzler, T. 1995. Water channels in plants: Do basic concepts of water transport change? - J. Exp. Bot. 46: 1067-1076.

- \& Heydt, H. 1988. An artificial osmotic cell: A model system for simulating osmotic processes and for studying phenomena of negative pressure in plants. - Plant Cell Environ. 11: $629-637$.

- , Zimmermann, U. \& Liuttge, U. 1977. Effects of turgor pressure and cell site on the wall elasticity of plant cells. - Plant Physiol. 59: 285-289.

Tardieu, F., Zhang, J. \& Davies, J. W. 1992. What information is conveyed by an ABA signal from maize roots in drying field soil? - Plant Cell Environ. 15: 185-191.

Turner, N. C. 1974. Stomatal behavior and water status of maize, sorgum and tobacco under field conditions. II. At low soil water potential. - Plant Physiol. 53: 360-365.

- 1981. Techniques and experimental approaches for the measurement of plant water status, - Plant Soil 58: 339-366.

- 1986. Crop water deficits: A decade of progress. - Adv. Agron. 39: 1-51.

- \& Long, M. L. 1980. Errors arising from rapid loss in the measurement of leaf water potential by the pressure chamber technique. - Aust. J. Plant Physiol. 7: 527-537.

Tyree, M. T. 1976. Negative turgor pressure in plant cells: Fact or fallacy? - Can. J. Bot. 54: 2738-2746.

- \& Jarvis, P. E. 1982. Water in tissues and cells. - In Encyclopedia of Plant Physiology (O. L. Lange, P. S. Nobel, C. B. Osmond and H. Zeiger, eds), New Series, Vol. 12B, Physiological Plant Ecology. II. Water relations and carbon assimilation, pp. 36-77. Springer-Verlag, Berlin. ISBN 3-540$10916-4$.

- \& Richter, H. 1982. Alternative method of analyzing water potential isotherms: Some cautions and clarifications. II. Curvilinearity in water potential isotherms. - Can. J. Bot. 60: 911-916.

- Patino, S., Bennink, J. \& Alexander, S. 1995. Dynamic measurements of root hydraulic conductance using a highpressure flow meter in the laboratory and field. - J. Exp. Bot. 46: 83-94.

Yang, S. \& Tyree, M. T. 1994. Hydraulic architecture of Acer saccharum and $A$. rubrum: Comparison of branches to whole trees and the contribution of leaves to hydraulic resistance. - J. Exp. Bot. 45: 179-186.

Voznesenskii, V. L. 1988. Do desert plants absorb water vapor from the atmosphere? - Sov. J. Plant Physiol. 35: 259-262.

Zhu, G. L. 1996. A new turgor/membrane potential probe simultaneously measures turgor and electrical membrane potential. - Bot. Acta 109: 51-56.

Zimmermann, M. H. 1983. Xylem Structure and the Ascent of the Sap, pp. 47-62. - Springer-Verlag, Berlin. ISBN 3-54012268-0.

Zimmermann, U. \& Steudle, E. 1978. Physical aspects of water relations of plant cells. - Adv. Bot. Res. 6: 45-177.

- , Benkert, R., Scheider, H., Rygol, J., Zhu, J. J. \& Zimmermann, G. 1993. Xylem pressure and transport in higher plants and tall trees. - In Water Deficits. Plant Response from Cell to Community (J. A. C. Smith and J. F. Griffiths eds), pp. 87-108. Bios Scientific Publishers. ISBN 1-87274806-6.

- , Zhu, J. J., Meinzer, F, C., Goldstein, G., Schneider, H., Zimmermann, G., Benkent, R., Thürmer, F., Melcher, P., Webb, D. \& Haase, A. 1994. High molecular weight organic compounds in the xylem sap of mangroves: Implications for long-distance water transport. - Bot. Acta 107: 218-229. 
This document is a scanned copy of a printed document. No warranty is given about the accuracy of the copy. Users should refer to the original published version of the material. 